\title{
TRIPLE BOTTOM LINE IN GREEN SUPPLY CHAIN MANAGEMENT: A CHEMICAL INDUSTRY STUDY
}

\section{Etienne Cardoso Abdala etienneabdala@hotmail.com Federal University of Uberlândia - UFU, Uberlândia, Minas Gerais, Brazil.}

\section{Eder J. de Oliveira}

admintegral@fagen.ufu.br Federal University of Uberlândia - UFU, Uberlândia, Minas Gerais, Brazil.

\section{Luciana Oranges Cezarino} Icezarino@gmail.com Federal University of Uberlândia - UFU, Uberlândia, Minas Gerais, Brazil.

\begin{abstract}
The management of the green supply chain aims to add practices to preserve the environment in the integrated network of supplies, in order to minimize the use of natural resources and to increase the use of the reuse of materials. The purpose of this article is to identify sustainable practices used by chemical industries of the Triple Bottom Line. Semi-structured interviews were carried out with mangers of medium and small business enterprises. Results show that sustainability is present in both; however, not fully completely obeying the sustainability tripod concept. The medium-sized company has a higher development of its environmental practices and could be considered as a focal company between the supply chain and their suppliers. Small businesses have to develop strategies, especially in terms of providing legal compliance to maintain their partnership with suppliers. None of them performed literature practices of a Green Supply Chain, but the first company, medium sized is ahead in terms of sustainable practices.
\end{abstract}

Keywords: triple bottom line; sustainable practices, chemical industry, small and medium enterprises (SME). 


\section{INTRODUCTION}

Since environmental concerns aroused the interest of individuals and organizations, much has been discussed about this matter. The World Commission Committee on Environment and Development (Brundtland, 1987) had brought the exploitation of natural resources and environmental destruction to light, obtaining international recognition among society, companies, NGOs, researchers, and other economic agents. One of the main results of the commissions' work was the creation of the concept of sustainable development, the ability to meet the needs of the present generation without compromising the needs of future ones. Sustainability has three dimensions that relate: economic, environmental and social. These dimension compounds of the Triple Bottom Line concept were developed by John Elkington (2001).

Thus, the environmental concern has spread, and organizations found themselves under pressure to comply with environmental laws and standards in their practices, adopting a sustainable approach and respect for the environment and society (Claro et al., 2008). However, much has to be done in order to understand this concept inside organizations, because sustainability can perform different elements in a social technical system, such as organizations or enterprises. Barbieri et Cajazeira (2009) illustrate that the concept of sustainable business is the one that incorporates in its policies and practices the concepts and objectives related to sustainable development in a consistent order.

However, it is not enough for a company to incorporate sustainable management practices in their operations to meet the sustainability requirements. This, in turn, depends on others to provide their offer to the market. In this sense, the supply chains emerge, and their concept refers to the division of the activities of a production chain by the different agents that directly contributed to the development of a product or service to the consumer or end user (Carvalho et Barbieri, 2006).

In order to broaden the discussion, Seuring et Muller (2008), Carter et Rogers (2008), and Pagell et Wu (2009) consider that the sustainable supply chain is an integrated and coordinated network of owned organizations of a production chain, developing sustainable actions in the social and environmental spheres, so as to achieve their economic goals.

The sustainable practices of the companies and supply chains are relevant and should be aligned with triple bottom dimensions. According to Dias (2010), through sustainability, the company can be economically viable and generate value to its shareholders, provide better working conditions and welfare for the society and obtain eco-efficiency of its production processes in addition to adopting an organizational environmental culture and environmental responsibility posture.

Therefore, the purpose of this article, considering the relevance of the chemical industry supply chain in Brazil, is to identify sustainable practices used by two companies located in the city of Uberlândia (MG) and analyze the implications of these actions in the social, environmental and economic dimensions. We chose to use the multiple-case study with semi-structured interviews with the managers to understand and describe in depth the issues in these two companies, which are both Small and Medium Enterprises (SME). The analysis of the information collected was carried out by categorizing data by content analysis.

\section{LITERATURE REVIEW}

\subsection{Sustainability and Triple Bottom Line}

The definition of sustainability became known worldwide from the Brundtland Report in 1987 (Brundtland, 1987), and since then, companies found themselves under pressure to meet environmental standards in their processes. In this sense, the development of social responsibility and sustainability in organizations drew the attention of managers, due to the possibility of generating value and demonstrating respect for society and the environment (Barbieri et Cajazeira, 2009).

Over the years, the subject became popular, and today it is a range of meanings involving sustainability and sustainable development, creating difficulties in implementing the discourse of sustainable practices by companies and their employees (Claro et al., 2008). To understand the foundations that underlie the concept of sustainability and explain their development, Faber et al. (2005) consider "what sustainable means," "orientation for the purpose", considering that sustainability implies changes (characterized as absolute or relative) and "behavioral interaction" since sustainability has considerable relations with the environment (the interaction can be static or dynamic).

Claro et al. (2008) state that, although there are many theoretical efforts, there is a lack of consensus on the meaning attributed to sustainability. The fact is that most studies argue that sustainability has three dimensions that relate: economic, environmental and social. These dimensions make up the Triple Bottom Line, also known as the triple bottom line, whose concept was developed by John Elkington (Elkington, 2001), and used by various authors. 
Brazilian Journal of Operations \& Production Management

Volume 15, Número 1, 2018, pp. 162-172

DOI: 10.14488/BJOPM.2018.v15.n1.a15
The economic, social and environmental dimensions are directly related to sustainable development in organizations and are described in Dias (2010): the economic point of view of sustainability provides that the role of business in society is to be economically viable, i.e. to return to investment by means of private capital. In social terms, the company must provide the best working conditions, taking into account cultural differences and providing opportunity to the disabled in general and the participation of its leaders in socio-cultural activities. From an environmental point of view, the organization should seek eco-efficiency of its production processes, adopt cleaner production, develop an organizational environmental culture and adopt an environmentally responsible attitude.

The three dimensions of sustainability (economic, environmental and social) are also considered in Pedroso et Zwicker (2007) by emphasizing the concept of corporate sustainability, namely business management that seeks to balance economic commitment to environmental preservation and the development of society, taking responsibility for current and future living conditions. Fauzi et al. (2010) reinterpret the triple bottom line and propose the concept of sustainable business performance derived from interactions within the tripod of sustainability. For these authors, this concept is more dynamic than static, because the constituent elements vary between contexts and over time. It is also interactive with respect to the continuous monitoring needed to be done in order to adapt its measures to changes involving the market and society.

\subsection{Sustainable supply chain management}

Supply chain management is an integrating management processes (production, distribution, use, etc.) to add value to customers and the public interested in the company's activities. It is clear that this definition can be increased with the dimensions of sustainability (economic, social and environmental) presented by Dias (2010), thus highlighting the management of the chain of sustainable supplies.

However Finger et al. (2010) found that aspects of sustainability played by companies are not always aligned with supply chain management and that these are concerned primarily to maintain the focus on organizational commitment, the internal flow of the supply chain and in the relationship with suppliers, which would undermine the concept of management of a sustainable supply chain. According to the authors, convergence between sustainability and the management of the supply chain will happen when there is a formal culture of sustainability.
To maintain sustainability in the supply chain can be the result of two elements: sustainable practices and induction of these practices by the focal company. Therefore, this induction happens for a dynamic relationship between suppliers, focal company and customers, exploring activities such as training, environmental auditing, logistics activities, environmental marketing, workshops/lectures, monitoring, evaluation, selection and auditing of suppliers (Arantes et al., 2014).

The thoughts of Seuring et Muller (2008) consist of external pressures and incentives made by consumers, NGOs, government and stakeholders. When the focal company is under pressure, it usually transfers such pressure to their suppliers, which implies a monitoring of the product supply chain to meet their pure economic needs. However, this interaction emerges from barriers or support factors that may hinder or facilitate communication of the focal company with its suppliers. These factors stimulate obtaining information on the environmental and social performance in the individual stages of production and the development of the leading suppliers (Seuring et Muller, 2008).

Shibao et al. (2014) understand how to process the relationship between business strategies of Green Supply Chain Management (internal practices, external, green investments, eco design and reverse logistics), the green profile (proactive and reactive corporate) and performance measures (environmental, economic and operational) in Brazilian chemical industries. Their results showed that proper management of green supply chain, implemented by environmental practices, results in superior performance, whether environmental, economic or operational. In a study to understand the practical implications of the sustainability concepts embodied in a focal company, Brock et Gavronski (2012) illustrate the need to develop methods and tools to make both the factory and the supply chain more sustainable; however, it is observed that, even if the focal company adopts concepts of sustainability, they are sometimes not fully adopted throughout the chain, generating constraints through suppliers.

However, for achieving sustainability throughout the supply chain, the relationship between supplier and focal company has to be strong. The focal company will ensure the management of sustainable supply, selecting, evaluating and collaborating with their suppliers, as well as the use of its internal resources and capabilities (Ageron et al., 2012; Hollós et al., 2011; Paulraj, 2011).

\subsection{Sustainable supply management}

The management of sustainable supplies mainly concerns the relations with suppliers. They are selected, eval- 
uated, and play along with the focal company and their role of environmental collaboration. This collaboration also allows the companies involved to cooperate with their suppliers in order to develop environmental strategies and provide them with materials, equipment, specifications and services to support environmental objectives (Paulraj, 2011).

In the supplier selection process some criteria are taken into consideration such as price, reliability, quality, delivery performance, size and location. The strategic vision incorporating long-term collaborative relationships and its commitment to sustainable development are also examples of supplier practices to be identified (Ageron et al., 2012). Paulraj (2011) highlights the creation of environmentally friendly products, internal operations and environmental performance, as evaluative sources of suppliers. The author also describes that those environmental indicators, such as emissions, waste, use of hazardous materials, environmental accidents and waste of energy, can measure performance.

Environmental practices, such as reducing the consumption of natural resources, manufactured under ecological standards and reduced energy consumption, are examples (Hollós et al., 2011). As highlighted by eco-efficiency, in the economic dimension, companies can produce the same quantity of products with less or the same level of resources, if using traditional methods, providing a reduction in the unit costs of the items purchased (Hollós et al., 2011).

Environmental issues that ensure the flow of materials through the chain while preserving the environment include suppliers' practices. They can be waste reduction, adherence to ISO 14001, cleaning programs, eco design, evaluation of life cycle, reverse logistics, manufacturing and, reduction of transport costs (Ageron et al., 2012). In addition, by ensuring the flow of materials through environmental practices, the company can also increase the sustainability of its base supply through two options: select and accept only sustainable suppliers and cooperate with existing or new suppliers to achieve high levels of sustainability (Hollós et al., 2011).

Ageron (2012), on building a sustainable supply management model, highlight internal and external reasons for this management. Among the external reasons, these stand out: the nature of the business, the need for regulation, competition and actions of stakeholders. Vision and top management commitment, supplier's initiatives and customer demand are configured as internal reasons. As the concept of sustainability addresses the social dimension, this is created by generating social welfare, health and community safety, occupational health and safety of

Table 1. Characteristics of Sustainable Supply Management or Green Supply Chain Management (GSCM)

\begin{tabular}{|c|c|c|c|}
\hline \multirow{2}{*}{$\begin{array}{c}\text { GSCM } \\
\text { Characteristics }\end{array}$} & \multicolumn{3}{|c|}{ Theoretical Models } \\
\hline & Paulraj (2011) & $\begin{array}{c}\text { Ageron, Guanasekaran e Spal- } \\
\text { anzani (2011) }\end{array}$ & Hollos, Blome e Foerstl (2011) \\
\hline $\begin{array}{l}\text { Collaboration be- } \\
\text { tween suppliers and } \\
\text { focal firm }\end{array}$ & $\begin{array}{l}\text { Environmental strategies cooperation } \\
\text { and development } \\
\text { Materials and equipment suppliers } \\
\text { Environmental goals for support } \\
\text { services } \\
\text { Control and evaluation of internal } \\
\text { operations }\end{array}$ & $\begin{array}{l}\text { Long-term collaboration (strategic } \\
\text { partnership) } \\
\text { Commitment to sustainable devel- } \\
\text { opment } \\
\text { Selection of suppliers as price, } \\
\text { quality, reliability, degree of depen- } \\
\text { dence, size, location. }\end{array}$ & $\begin{array}{l}\text { Sustainable cooperation between } \\
\text { purchasers and suppliers }\end{array}$ \\
\hline $\begin{array}{l}\text { Management Ap- } \\
\text { proach and Relation- } \\
\text { ship Orientation }\end{array}$ & $\begin{array}{c}\text { Collaborative } \\
\text { Environmental and Entrepreneurship } \\
\text { (proactivity) }\end{array}$ & Proactive guidance & $\begin{array}{l}\text { Strategic orientation - integration } \\
\text { of strategic plans }\end{array}$ \\
\hline $\begin{array}{l}\text { Pressures, external } \\
\text { factors and reasons } \\
\text { for sustainability in } \\
\text { GSS }\end{array}$ & $\begin{array}{l}\text { Competitive advantage - increasing } \\
\text { opportunities of market share } \\
\text { Promotion of improved corporate } \\
\text { image and brand image } \\
\text { Reputation and social legitimacy }\end{array}$ & $\begin{array}{c}\text { Regulatory requirements } \\
\text { Business Nature } \\
\text { Actions of stakeholders, including } \\
\text { non-governmental organizations' } \\
\text { actions } \\
\text { Competitors }\end{array}$ & $\begin{array}{l}\text { Search for improvement in organi- } \\
\text { zational performance } \\
\text { Impact on the competitive position }\end{array}$ \\
\hline Internal factors & Strategic Purchasing Process & $\begin{array}{l}\text { Vision and commitment of top } \\
\text { management } \\
\text { Customer requirements } \\
\text { Sustainable initiatives suppliers } \\
\text { Design sustainable products and } \\
\text { processes } \\
\text { Pollutant emission reduction }\end{array}$ & $\begin{array}{l}\text { To provide sustainability value in } \\
\text { the supply base, generating ben- } \\
\text { efits for the purchasing company } \\
\text { and its suppliers } \\
\text { Reducing costs and improving the } \\
\text { quality and innovation }\end{array}$ \\
\hline
\end{tabular}


employees (Paulraj, 2011). Hollos et al. (2011) present other social practices, such as better working conditions, proper wages, better prepared workplace and leisure time between shifts. Once employees are motivated, these practices contribute to the reduction of waste and defective parts.

Thus, two categories divide sustainable supply management: characteristics and practice of sustainable supply management. Tables 1 and 2 represent these categories. Table 1 concerns the sustainable supply management features, according to the authors mentioned above.

Table 2 shows sustainable practices to be evaluated in focal suppliers companies, in order to preserve the sustainability throughout the supply chain. The same authors from Table 1 provide base for such practices.

\section{METHOD PROCEEDINGS}

This research is qualitative. It is not interested in the measure or quantifications of the events, not even employs statistical tools for data analysis. In order to fulfill its general objective the research technique was the case study, because it seeks to interpret a phenomena and the relationship between these phenomena (Yin, 2001).

We identified companies in the industrial sector; specifically, chemicals manufacturing companies, located in the city of Uberlândia, Minas Gerais, Brazil. Chemical industry is responsible for supplying relevant supply chains for the country's economic development, such as construction, oil/gas, automotive industry, among others, which therefore participate in major supply chains for economic development (Brazilian Association of Chemical Industry, 2010).

Nevertheless, for identification and further analysis of environmental practices, it is necessary to identify what sustainable practices are, actually, carried out by focal companies. The qualitative interview, according to Bauer et Gaskell (2002), serves as the entry point for researchers to map and understand the world of respondents and from this point, the social scientist introduces interpretive schemes to understand the narratives of social actors. Qualitative interviews followed by semi-structured ones that have been developed in addition to identifying such sustainable practices, providing discussions between interviewer and interviewee in order to contribute to further analysis. The script with the appropriate questions was based on practical and sustainable supply management features, as found in the literature presented on sustainable/green supply management (GSCM).

Among the features in the script questions, are the "Collaboration between suppliers and focal enterprise", "Management approach / orientation of the relationship," "Pressures, external factors and reasons for sustainability in GSS" and "Internal factors". Practices configure "Environmental Practices (or Green)" and "Social Practices". Both characteristics and practices are divided into subdivisions as discussed previously in the theoretical framework. These aspects were extracted from the studies of Ageron et al. (2012), Paulraj (2011) and Hollos et al. (2011).

Table 2. Characteristics of Sustainable Supply Management

\begin{tabular}{|c|c|c|c|}
\hline \multirow{2}{*}{$\begin{array}{c}\text { GSCM } \\
\text { Practices }\end{array}$} & \multicolumn{3}{|c|}{ Models } \\
\hline & Paulraj (2011) & $\begin{array}{l}\text { Ageron, Guanasekaran e Spalanzani } \\
\text { (2011) }\end{array}$ & Hollos, Blome e Foerstl (2011) \\
\hline $\begin{array}{l}\text { Environmental Practices (or } \\
\text { Green) }\end{array}$ & $\begin{array}{l}\text { Production of environmentally } \\
\text { friendly goods and environmen- } \\
\text { tal performance } \\
\text { Emissions, losses, consumption } \\
\text { of materials that harm the envi- } \\
\text { ronment } \\
\text { corporate environmental acci- } \\
\text { dents } \\
\text { Energy savings in production }\end{array}$ & $\begin{array}{l}\text { Selection of suppliers and environ- } \\
\text { mental certification } \\
\text { Loss Reduction } \\
\text { Adherence to ISO } 14001 \\
\text { Lean production } \\
\text { Eco design } \\
\text { Clean production programs and } \\
\text { reducing emissions of pollutants } \\
\text { Product life cycle assessment } \\
\text { Reducing transportation costs } \\
\text { Reverse logistics and manufacturing }\end{array}$ & $\begin{array}{c}\text { Loss Reduction } \\
\text { Conservation of natural } \\
\text { resources } \\
\text { Reduced power consumption } \\
\text { Preventive actions to reduce } \\
\text { damage to the environment } \\
\text { Production of products } \\
\text { according to environmental } \\
\text { standards } \\
\text { Eco efficiency }\end{array}$ \\
\hline Social practices & $\begin{array}{c}\text { Promotion of social welfare, } \\
\text { health and safety in the com- } \\
\text { munity } \\
\text { Risks to the general public } \\
\text { Occupational health staff }\end{array}$ & $\begin{array}{l}\text { Selection of suppliers for socially } \\
\text { responsible practices development }\end{array}$ & $\begin{array}{l}\text { Products according to social } \\
\text { standards } \\
\text { Socially responsible behavior } \\
\text { Promotion of good working } \\
\text { conditions } \\
\text { Safety standards and appropri- } \\
\text { ate wages }\end{array}$ \\
\hline
\end{tabular}


Thus, the semi-structured interviews were conducted with the responsible employee for the environmental area of the selected focal organization. This was because they had knowledge of the composition of their products, raw materials purchased and used in the production process, certifications requirements and relationship with its suppliers. The script of the questions for the semi-structured interview was first applied to the quality area manager and responsible for the actions and environmental practices of medium-sized organization. The second interview was applied to the responsible manager for sustainable practices in the small company.

In order to interpret the content of the interviews with the managers, the content analysis technique was used. According to Bardin (1977), such technique is represented by a set of analysis techniques of communications through objective and systematic procedures description of the content of messages, allowing the researcher to draw inferences (logical deductions) of the studied object. The content analysis resulted on categories that helped the inference, understanding and closeness of elements with similar meanings regarding the environmental practices of both. These categories were drawn from the literature review. Figure 1 shows the formation of the categories of analysis:

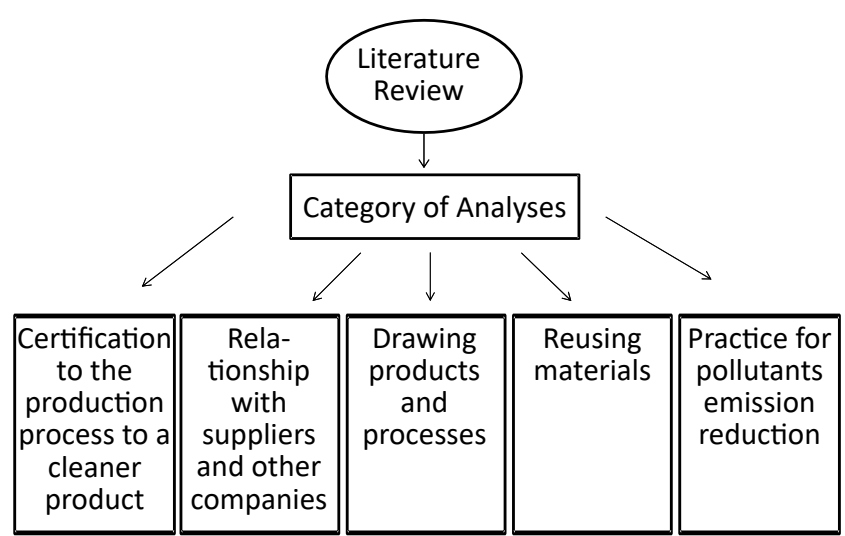

Figure 1: Development of analytical categories. Source: Authors

\section{PRESENTATION AND CLASSIFICATION RESULTS}

This section provides the description of both studied cases, the small and the medium sized companies.

\subsection{Company $X$}

The company $X$ is in the market for over 20 years. It covers 23 states acting through their direct representatives or trough national distributors. Occupying an area of 20,000 square meters Company $X$ has 190 direct employees and 500 indirect working on their premises. Its main product and the best-selling is the automotive wax, as about 90 thousand boxes are sold annually. Due to the line of business of the company $X$ it is classified as a sanitizing industry that has, as one of its goals, making disinfection products, household cleaning, in addition to having two more lines of cleaning products.

Through the interview it can be seen that the company $X$ considers sustainability in its operations. This consideration reflexes in the attitudes of owners and senior managers who recognize the benefits that sustainability can bring. This became clear once the handling and marketing of its products, "Arla 32", came through an idea of their owners. Company $\mathrm{X}$ is the first industry in the region certified to produce "Arla 32", developed by Petrobras. It is a liquid reducing agent of emissions of nitrogen oxides (NOx), developed for vehicles powered by diesel oil produced from 2012, with the new SCR technology (Selective Catalyst Reduction) (Petrobras, 2015). This is a product for the de-pollution of the environment acting in the exhaust catalysts of truck and bus engines, allowing a reduction in emissions of particulate matter (Petrobras, 2015).

In its activities with suppliers, the company $X$ cooperates with them making the return of reusable bottles in the process, rather than simply selling them recycled. As the proximity of suppliers and the operating time with the company, they are encouraged to use recycled pet in their production process. The company selects its suppliers by three main factors: the quality of its products, socio-environmental practices, and compliance as the deadline. The cost factor is considered; but according to the interviewed it is less important than the social practices. The suppliers social practices are carried out monitored by company $X$. As for certifications, these are not mandatory, but count as a positive factor for the choice of suppliers.

Company $\mathrm{X}$ also has the Waste Management Program (SWMP) in which it maintains contact with other recycling companies and writes reports on the amount of solid waste (scrap metal, glass, plastic, cardboard) it generates annually. Although the company $X$ suffers government pressure to issue these reports, it is not under pressure of its customers, as requirement for sustainable products.

About materials reuse practices, the respondent pointed out that, although the company has not yet succeeded in making compost, it can reuse the waste in co-processing casting bricks. Yet, due to the SWMP, the company $X$ can reuse plastic and plastic bags in its own process. Although the materials reuse practices the company has the "reprocessing" into two categories: the practice with liquid waste 
Table 3. Sustainable Practices Company X

\begin{tabular}{|c|c|}
\hline Category & Sustainable practices of company $X$ \\
\hline $\begin{array}{l}\text { Certification to the produc- } \\
\text { tion process to a cleaner } \\
\text { product }\end{array}$ & $\begin{array}{l}\text { First industry in the region to have the certificate for the production of Arla 32. The product acts in the } \\
\text { reduction of emission of oxides of nitrogen. }\end{array}$ \\
\hline $\begin{array}{l}\text { Relationship with suppliers } \\
\text { and other companies }\end{array}$ & $\begin{array}{l}\text { Cooperation with a few suppliers with regard to returnable packages lost in the production process for } \\
\text { the originating company or other companies; } \\
\text { Encourage suppliers to use recycled PET in the production process; } \\
\text { Waste Management Program (SWMP) in one of the performances is the company's interaction with } \\
\text { suppliers and other recycled companies having a higher performance with the last; } \\
\text { Monitoring of environmental activities mentioned by suppliers. }\end{array}$ \\
\hline $\begin{array}{l}\text { Drawing products and pro- } \\
\text { cesses }\end{array}$ & $\begin{array}{l}\text { Manufacture of biodegradable packaging; } \\
\text { Decision making for the most suitable raw material in financial terms, but it can also be natural, from } \\
\text { legally licensed suppliers, and are organized in all its parts' management regarding sustainability. }\end{array}$ \\
\hline Reusing materials & $\begin{array}{l}\text { Reuse of waste as co-processing casting bricks; } \\
\text { Plastic parts and plastic bags recycling; } \\
\text { All liquid waste that were lost in the process, but were not full form contaminated are reused in subse- } \\
\text { quent batches by the company. } \\
\text { If the packaging TAD (high density polyethylene) is slightly rumpled and not contaminated with the } \\
\text { product, the company can grind such a bottle and enjoy it again as raw material in the production line. }\end{array}$ \\
\hline $\begin{array}{l}\text { Practice for pollutants emis- } \\
\text { sion reduction }\end{array}$ & $\begin{array}{l}\text { Use of LPG boiler instead of wood chips, producing less waste in the process. LPG is the fuel used in } \\
\text { the smelting process, which for the company X is more viable economically and also environmentally } \\
\text { speaking (not emit as much particulate material or hydrogen peroxide). }\end{array}$ \\
\hline
\end{tabular}

Source: Authors

and the packaging TAD (high density polyethylene). Company $X$ can reuse all the liquid wastes that have been lost in the process, but not contaminated totally, using them in subsequent batches.

The practice of reducing emissions of pollutants used by company $X$ is the use of LPG boiler (Liquefied Petroleum Gas) instead of using the wood chips that generate more waste compared to the boiler. According to the respondent, the company uses LPG for the casting process, for better economic results, because it is more feasible for the company, and does not emit hydrogen oxide and or particulate matter.

Sustainable practices developed by the company $X$ can be better understood by means of Table 3 :

The company has a training center for children and adolescents 7-15 years of age, and promotes the formation and physical, social, cultural and intellectual development of its participants. This training center known as X Institute, offers its participants, computer workshops, arts, capoeira, hip-hop and jazz. Some employees of company $X$ are volunteers in this program, as well as some of the Institute's beneficiaries had the opportunity to work in the factory of the company X. Still in its social policies, the company $X$ has the Good Manufacturing Practices program, linked to the ideal working conditions, such as safety equipment, clean and pleasant environment, preventive and corrective maintenance, among others.
Table 4 presents a summary of activities undertaken by the company $X$ in the environmental, social and economic of the Triple Bottom Line.

\subsection{The Case of Company $Y$}

The company $Y$ is located in the city of Uberlândia and is in the market since 1983. Its mission is to earn and maintain the reputation of competitive and reliable supplier in the market in which it operates. Its main activity is to provide cleaning and maintenance of industrial products. Even at the beginning of its activities, when the concern for sustainability was not as influential as today, the company $Y$ was concerned to provide biodegradable products to its customers, with the commitment to approval by the Ministry of Health. It currently has large customers in various sectors of the economy, such as steel mills, mining, extractors, manufacturers, businesses linked to construction, among others. It has an average of 30 employees and its main product takes grease.

Among the activities performed with suppliers, their raw material evaluation system is worth mentioning. Once they decided to manufacture a product or acquire any material, the process prompts suppliers to send a sample of the raw material. Therefore, this goes through several quality and evaluation and validation tests. If the raw material is in usable condition, company $Y$ begins manufacturing it. If the raw material is not approved, the company immediately reports to suppliers the negative aspects of supply 
Table 4. The Triple Bottom Line in Company X

\begin{tabular}{|c|c|c|}
\hline Dimension & Company X's activities \\
\hline Environmental & $\begin{array}{r}\text { Adoption of cleaner production by replacement of wood chips by liquefied petroleum gas boiler; } \\
\text { Eco Range efficiency through waste reuse as co-processing casting bricks, plastic and reuse plastic bags, liquid } \\
\text { waste reuse in subsequent batches and reuse of high-density polyethylene packaging; } \\
\text { Development of an organizational culture focused on sustainability by the owner and environmental responsibility } \\
\text { stance with suppliers through partnerships and monitoring (packaging feedback and monitoring of suppliers). }\end{array}$ \\
\hline Social & $\begin{array}{r}\text { Managing a center for physical, social, cultural and intellectual of children and adolescents, offering its partici- } \\
\text { pants, computer workshops, arts, capoeira, hip hop and jazz; } \\
\text { Promotion of better working conditions through the program Good Manufacturing Practices linked to the ideal } \\
\text { working conditions, such as safety equipment, clean and pleasant environment, and preventive and corrective } \\
\text { maintenance. }\end{array}$ \\
\hline Economic & $\begin{array}{r}\text { Maintenance of positive results for the reuse of materials allowing the company's expansion in the country; } \\
\text { Investments in research and development result in economically viable and easy marketing products, such as } \\
\text { automotive wax. }\end{array}$ \\
\hline
\end{tabular}

and indicates possible solutions for optimal performance. Therefore, it is a system that maintains the quality of products for enterprise $Y$ and also develops and reports through feedback, possible defects and solutions for the development of supplies from its suppliers.

The support for the use of sustainable practices also comes from top management. Executives conduct technical visits by the premises of its suppliers and other companies in the industry to understand how the process of packaging and other production line process is done, bringing new knowledge to the company $\mathrm{Y}$. In its production process, contaminated waste and not contaminated are identified and separated for their reuse by a third party. Y Company's products are transported in containers and, when they are not consumed, they return to the company and are reused in other ends.

When it comes to product design and processes, the company has significant concerns about the purity of acids, essences and biodegradable materials. It is imperative that their supplies and materials follow strict quality standards for continued product development process. All these processes are inspected and monitored by the company's regulation and market prices.

In order to reduce pollutant emissions, $Y$ Company replaced the steam generator by LPG boiler that pollutes less; however, it does not exempt the company writing pollutant reports from time to time. These reports are related to organs and municipal inspection programs, such as the Federal Police Department of the Environment, Army, Effluent Monitoring Program (PREMEND) and National Council of the Environment (CONAMA). These reports are essential for products sales to large customers and are required to carry out certain purchases from suppliers.

Despite the environmental certificates, Company $Y$ requires mandatory documents in the buying process. The company does not suffer pressures from their customers for requirements of sustainable products.

The environmental practices developed and used by company $Y$ are in Table 5:

Table 5. Sustainable Practices of Company $Y$

\begin{tabular}{|c|c|}
\hline Category & Sustainable practices of company $Y$ \\
\hline $\begin{array}{l}\text { Relationship with suppliers and } \\
\text { other companies }\end{array}$ & $\begin{array}{l}\text { System evaluation of raw material suppliers capable of indicating improvements and defects, con- } \\
\text { tributing to the improvement of the received supplies; Visits to supplier companies by the executive } \\
\text { board to meet packaging processes and other production line processes. }\end{array}$ \\
\hline Reusing materials & $\begin{array}{l}\text { When the client does not need the containers that are used for the delivery of goods, they return } \\
\text { the company to be reused; The company makes the distinction between contaminated waste and } \\
\text { uncontaminated, which is reused by a third party. }\end{array}$ \\
\hline Drawing products and processes & $\begin{array}{l}\text { The priority of using biodegradable raw materials in the design of their products and processes; } \\
\text { If a raw material is rejected in quality testing its development is suspended; The product develop- } \\
\text { ment activities are monitored by senior management. }\end{array}$ \\
\hline $\begin{array}{l}\text { Practices for pollutants emission } \\
\text { reduction }\end{array}$ & $\begin{array}{c}\text { Use of LPG boiler to replace the steam generator, which pollutes more, compared to the boiler } \\
\text { mentioned above. }\end{array}$ \\
\hline
\end{tabular}


Among the social practices performed by company $\mathrm{Y}$, such as cleaning the workplace, concerns about the lighting, the organization of materials (making them available in order to facilitate access) and use of safety equipment, the company has seals as contributions to social entities, one of them awarded to companies that contribute to a local hospital, and another related to the employability of young people aged 16 to 24 years. In addition to these sales, the company contributes to the support of missionaries of a religious organization.

The company $Y$ does not require its suppliers to have environmental certifications; however, in the purchasing process, it is required that they have legal mandatory documentation. The interviewee said that the company does not worry about identifying their suppliers issues related to environmental protection and social responsibility, but reported that harmful actions to the environment, carried out by its suppliers, may have negative impact on the relationship. According to the interviewee the company can gain competitive advantage and increased market share through sustainability, since the Y Company has ISO 9001 and uses biodegradable raw material in its products, two factors that facilitate and make obtaining advantages and superior performance.

Table 6 shows the activities of the company related to the Y Triple Bottom Line.

\section{FINAL CONSIDERATIONS - COMPARATIVE ANALYSIS BETWEEN CASES}

We are able to highlight certain similarities and differences between cases. The cases address two chemical plants located in the same city and they sell most of their products for wholesale. To analyze how the two companies work together with their suppliers, it is clear that both seek to establish links, though, differently.

Company $Y$ practices include physical visits to supplier's facilities to meet new processes, system of evaluation of raw materials, feed ratio backs and improvements of the received inputs from its suppliers. Company $Y$ does not seek to drive sustainable practices to its suppliers or distributors, always looking to keep up with environmental regulations, and produce quality products while respecting environment. Company $X$, in turn, created a stronger bond with their suppliers, cooperating with the return packages lost in the production process, and makes its suppliers start using recycled $\mathrm{PET}$ in their processes. Company $\mathrm{X}$ also seeks to monitor the environmental activities of its suppliers through visits to their facilities.

Thus we can infer that the company $X$, unlike company $Y$, can be characterized as a focal company, as it induces sustainable practices to its suppliers. The company $X$ has great power in the chain of its flagship product, the automotive wax, influencing chain logistics in the country, which meets the definition mentioned by Seuring et Muller (2008). In terms of the application of sustainable practices, both the company $X$ and company $Y$ use LPG boiler (liquefied petroleum gas) in their processes, thus reducing the emission of pollutants (Ageron et al., 2012). In addition, they are configured as an action to control pollution, as discussed in Barbieri (2011).

About the characteristics taken into account in the choice of suppliers, the company $X$ has listed three main characteristics: quality of inputs, socio-environmental practices and compliance with the deadline. The quality of materials is also considered as a major factor in the choice of Y Company's suppliers. Other two are supplier's experience and price of their raw materials, reinforcing once again, the appeal to economic issues.

None of the industries are under pressure from their consumers on the requirements for sustainable products, but still considers sustainable practices in its product design and processes. Both have environmental law as the main source of influence, being required to develop and maintain reports that prove their legal status. These reports are even more relevant for Company $Y$, which are essential if it wants to keep large contracts with its suppliers, taking advantage of economies of scale.

Table 6. The Triple Bottom Line in Company Y

\begin{tabular}{|c|c|}
\hline Dimension & Company Y's activities \\
\hline Environmental & $\begin{array}{r}\text { Steam generator replacement by liquefied petroleum gas (LGP) boiler, establishing a cleaner production; } \\
\text { Obtaining eco-efficiency through the use of biodegradable materials in their products, the reuse of containers, } \\
\text { the checking of the best materials through its evaluation system of raw materials; Environmental posture devel- } \\
\text { oped by senior management and transmitted to the other organization of individuals. }\end{array}$ \\
\hline Social & $\begin{array}{r}\text { Achieving better working conditions providing safety equipment for its employees, worrying about cleaning the } \\
\text { workplace, its lighting and organization of materials; Supporting social development, to contribute to a hospital, } \\
\text { the employability of young people and the support of missionaries of a religious organization. }\end{array}$ \\
\hline Economic & $\begin{array}{r}\text { Can develop and perpetuate the market, using sustainability to close large contracts with companies in the fields } \\
\text { of steel mills, mining, extractors, manufacturers, and businesses linked to construction. }\end{array}$ \\
\hline
\end{tabular}


As Company $\mathrm{X}$ to be a medium-sized company, it can meet the requirements of this approach. While meeting the environmental aspects required by law, it advanced in terms of new practices, such as co-processing casting brick, the plastic recycling and liquid waste, as well as high-density polyethylene containers. For the smaller business, the economic dimension is more relevant, but not to obtain very satisfactory results; however, it has to align its production costs and legal certifications required by its suppliers.

In a sense, none of them could fulfill the triple bottom line, according to actions proposed in literature. Moreover, the medium sized Company $X$ presents a stronger social dimension, presenting an institute to social work and community support. Regarding this dimension, in company $\mathrm{Y}$, only society benefits are presented and sometimes-related to economic dimension as negative results.

One of the possible future studies is related to the development of more specific social practices that result in actions of the social dimension of sustainability. Many Brazilian companies do not care about the social dimension in terms of the individual, focusing especially on actions in social groups, such as the creation of foundations or associations that help poor communities.

\section{REFERENCES}

Ageron, B. et al. (2012), "Sustainable Supply Management: An Empirical Study", International Journal of Production Economics, Vol. 140, No.1, pp. 168-82.

Arantes, A. F. et al. (2014), "Adoption of Green Supply Chain Management practices: induction mechanisms and the importance of focal companies", Gestion \& Production, Vol. 24, No. 4, pp.725-34.

Brazilian Association of The Chemical Industry (2010), "National Pact of the Chemical Industry", available from: http://www.abiquim.org.br/pdf/Pacto_Nacional_Abiquim. pdf (access: 01 Aug 2015).

Barbieri, J. C. (2011), Corporate Environmental Management: Concepts, Models and Instruments, 3rd ed., Saraiva, São Paulo, p.358.

Barbieri, J.C.; Cajazeira, J. E. R. (2009), Corporate Social Responsibility and Sustainable Business: from theory to practice, Saraiva, São Paulo.

Bardin, L. (1977), Content Analysis, Editions 70, Lisbon.

Bauer, M. W.; Gaskell, G. (2002), Pesquisa qualitativa com texto, imagem e som: um manual prático, Vozes, Petrópolis, RJ.
Brock, V. F; Gavronski, I. (2012), "Incorporating Sustainability into Supply Chain Management: A Case Study at the Springer Carrier", in Symposium on Production, Logistics and International Operations Administration, 15., 2012, São Paulo. Anais... São Paulo.

Brundtland, G. H. (1987), Our Common Future: Report of the World Commission on Environment and Development, Oxford University Press, Oxford.

Carter, C. R.; Rogers, D. S. (2008), "The framework of sustainable supply chain management: moving toward new theory", International Journal of Physical Distribution \& Logistics Management, Vol. 38, No. 5, p. 360-87.

Carvalho, A; Barbieri, J. C. (2006), "Sustainability and Supply Chain Management: Concepts and Examples", in: Vilela Júnior, A; Demajorovic, J. (Org.), Models and tools of environmental management: challenges and perspectives for Organizations, 2nd ed., Senac, São Paulo, pp. 401-29.

Claro, P.B. O. et al. (2008), “Understanding the Concept of Sustainability in Organizations", Journal of Business Administration, Vol. 43, No. 4, p.289-300.

Dias, R. (2010), Environmental Management: Social Responsibility and Sustainability, Atlas, São Paulo, p. 198.

Elkington, J. (2001), Cannibals with fork and knife, Makron Books, São Paulo.

Faber, N. et al. (2005), "The sustainability of 'sustainability': a study into the conceptual foundations of the notion of 'sustainability'", Journal of Environmental Assessment Policy and Management, Vol. 7, No. 1, pp. 1-33.

Fauzi, H. et al. (2010), "Triple Bottom Line a sustainable corporate performance: the proposition for the future", Sustainability, Vol. 2., pp. 1345-60.

Finger, A. B. et al. (2010), "Sustainable Supply Chain Management: Analysis in Multiple Companies in the State of Rio Grande do Sul", in National Meeting of Production Engineering, 30., 2010, São Carlos. Anais... São Carlos.

Hollos, D. et al. (2011), "Does Sustainable Supplier Co-operation Affect Performance? Examining Implications for the Triple Bottom Line", International Journal of Production Research, pp. 1-19.

Pagell, M.; Wu, Z. (2009), "Building a more complete theory of sustainable supply chain management using case studies of 10 exemplars", Journal of Supply Chain Management, Vol. 45, No. 2, pp. 37-56.

Paulraj, A. (2011), "Understanding the Relationships Between Internal Resources and Capabilities, Sustainable Supply Management and Organizational Sustainability", Journal of Supply Chain Management, Vol. 47, No. 1, pp. 19-37. 
Pedroso, M. C.; Zwicker, R. (2007), "Sustainability in the Reverse Supply Chain: A Case Study of the Plasma Project", Management Review, São Paulo, Vol. 42, No. 4, pp. 414-30.

Petrobras (2015), Institutional Website, available from: http://www.br.com.br/wps/portal/portalconteudo/produtos/automotivos/arla32> (access: 30 April 2015)

Seuring, S; Muller, M. (2008), "From a literature review to a conceptual framework for sustainable supply chain management", Journal of Cleaner Production, Vol. 5, No. 16, pp.1699-1710.

Shibao, F. Y. et al. (2014), "Supply Chain Management Green: a comparison between Brazil, China and Japan", Contemporary Management, Porto Alegre, No. 16, pp.7290.

Yin, R. K. (2001), Case Study: Planning and Methods, 2nd ed., Bookman, Porto Alegre.

Received: Jan 21, 2018

Approved: Jan 28, 2018

DOI: 10.14488/BJOPM.2018.v15.n1.a15

How to cite: Abdala, E. C.; Oliveira, E. J.; Cezarino, L. O. et al. (2018), "Triple bottom line in Green Supply Chain Management: a chemical industry study", Brazilian Journal of Operations \& Production Management, Vol. 15, No. 1, pp. 162-172, available from: https://bjopm.emnuvens.com.br/bjopm/article/view/445 (access year month day). 